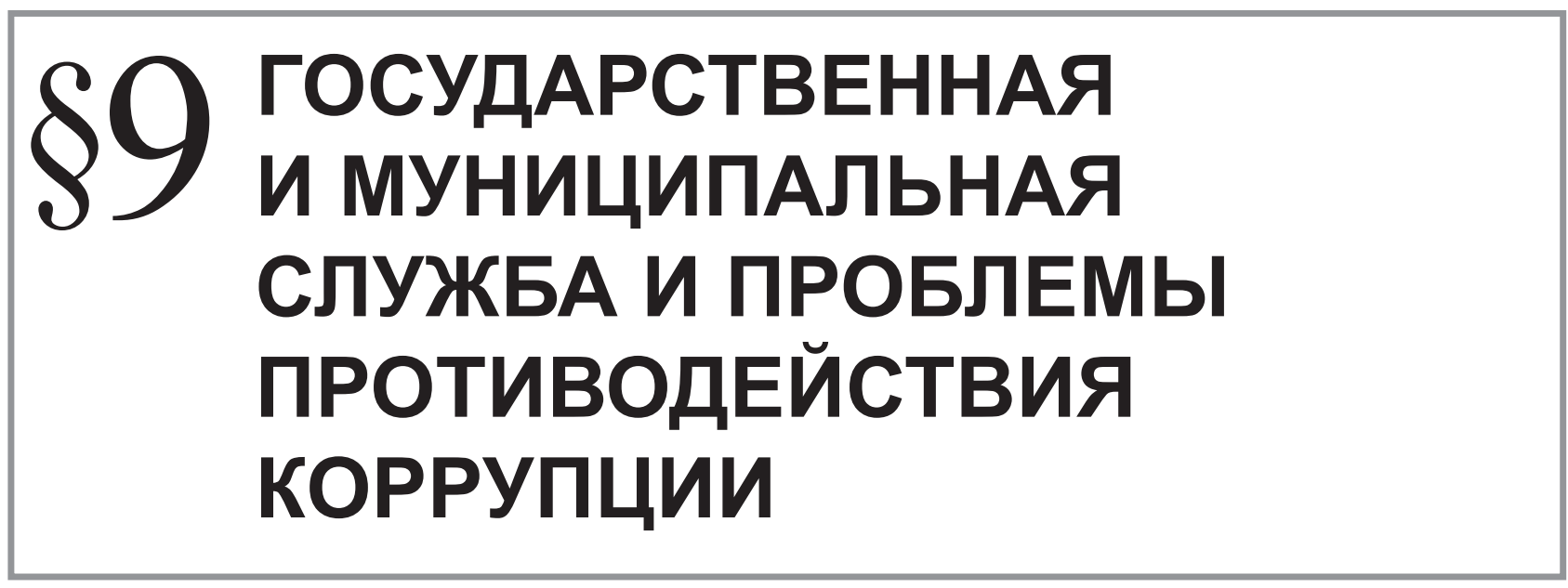

О.А. Слепкова

\title{
КЛАССИФИКАЦИЯ ВИДОВ АНТИКОРРУПЦИОННОЙ ЭКСПЕРТИЗЫ НОРМАТИВНЫХ ПРАВОВЫХ АКТОВ И ПРОЕКТОВ НОРМАТИВНЫХ ПРАВОВЫХ АКТОВ ФЕДЕРАЛЬНОЙ ТАМОЖЕННОЙ СЛУЖБЫ РОССИЙСКОЙ ФЕДЕРАЦИИ
}

$\mathrm{H}$ а современном этапе развития российского общества, на государственном уровне, признается, что коррупция в России приняла масштабный характер и наносит серьезный ущерб не только социально-экономическому благополучию государства, но и безопасности страны, в целом. На сегодняшний день эффективной мерой противодействия коррупции признается антикоррупционная экспертиза нормативных правовых актов и проектов правовых актов ${ }^{1}$.

Важным вопросом исследования института антикоррупционной экспертизы нормативных правовых актов и проектов правовых актов является выявление особенностей взаимосвязи элементов антикоррупционной экспертизы нормативных правовых актов и проектов правовых актов.

Для анализа указанной проблемы и определения некоторых особенностей антикоррупционной экспертизы нормативных правовых актов и проектов правовых актов ФТС России, считаем необходимым

Куракин А.В. Административные запреты и ограничения как средство противодействия коррупции в системе государственной службы // Административное и муниципальное право. - 2008. - № 1 . провести классификацию видов антикоррупционной экспертизы нормативных правовых актов и проектов правовых актов ФТС России.

Классификация определяется как распределение предметов по группам (классам), где каждый класс имеет свое постоянное, определенное место. ${ }^{2}$

В правовой доктрине основанием для классификации выступает комплекс признаков, которые включают в себя цели и сущность, а также сферу проведения экспертизы, различных субъектов экспертной деятельности.

И.А. Закиров, исследуя вопросы классификации правовой экспертизы, под классификацией правовых экспертиз понимает их разделение на отдельные классы (группы) как по существенным, так и не по существенным признакам на основе существующих у них сходств и различий. ${ }^{3}$

Действующее российское законодательство не содержит классификации антикоррупционной эксперти-

2 Михалкин Н.В. Логика и аргументация в судебной практике. СПб., 2004. С. 41.

3 Закиров И.А. Правовая экспертиза: дис. ... канд. юрид. наук. Н.Новгород, 2008. С. 10. 
зы нормативных правовых актов и проектов правовых актов, в том числе антикоррупционной экспертизы нормативных правовых актов и проектов правовых актов ФТС России. Вопрос классификации видов антикоррупционной экспертизы нормативных правовых актов и проектов правовых актов в той или иной степени затронут в юридической литературе. Проблемы классификации видов антикоррупционной экспертизы нормативных правовых актов и проектов правовых актов ФТС России учеными не рассматривались.

Считаем целесообразным провести классификацию антикоррупционной экспертизы нормативных правовых актов и проектов правовых актов ФТС России согласно типологии форм и видов антикоррупционной экспертизы. Основанием для классификации выступает комплекс признаков, которые включают в себя цели и сущность, а также сферу проведения экспертизы, различных субъектов экспертной деятельности, а также критерии, предложенные различными учеными применительно к антикоррупционной экспертизы нормативных правовых актов и проектов правовых актов.

Заслуживает внимания классификация видов антикоррупционной экспертизы нормативных правовых актов и проектов правовых актов, предложенная А.В. Кудашкиным. Ученый проводит классификацию антикоррупционной экспертизы нормативных правовых актов и проектов правовых актов в зависимости от предмета[3], считаем, что в соответствии с данными критерием можно дифференцировать антикоррупционную экспертизу нормативных правовых актов и проектов правовых актов ФТС России на:

- экспертизу нормативных правовых актов;

- экспертизу проектов нормативных правовых актов.

Следующее основание, предложенное А.В. Кудашкиным: по объему проводимого экспертного исследования антикоррупционную экспертизу правовых актов и проектов правовых актов[3]. Полагаем возможным на основании данного критерия провести следующую классификацию антикоррупционной экспертизы нормативных правовых актов и проектов правовых актов ФТС России:

- полная антикоррупционная экспертиза нормативных правовых актов и проектов правовых актов ФТС России, имеющая целью устранение всех коррупциогенных факторов, указанных в Методике проведения антикоррупционной экспертизы, а также иных выявленных коррупциогенных факторов, не включенных в нее;

- частичная антикоррупционная экспертиза нормативных правовых актов и проектов правовых актов
ФТС России, направленная на устранение всех коррупциогенных факторов, указанных в Методике проведения антикоррупционной экспертизы;

- неполная антикоррупционная экспертиза нормативных правовых актов и проектов правовых актов ФТС России, направленная на устранение какого-то одного или нескольких коррупциогенных факторов, не исчерпывающих их перечня, установленного действующей Методикой проведения антикоррупционной экспертизы. Причем, как справедливо отмечает А.В. Кудашкин к такой экспертизе можно отнести юридико-лингвистическую экспертизу нормативных правовых актов и проектов правовых актов.

А.В. Кудашкин подчеркивает, что данная Методика требует проведения антикоррупционной экспертизы в целях выявления только перечисленных в ней коррупциогенных факторов, которые являются частью возможных коррупциогенных факторов, что позволяет сделать вывод о частичном характере такой экспертизы.

По мнению А.В. Кудашкина наибольшее практическое значение имеет классификация в зависимости от степени обязательности. ${ }^{4}$ На основании данного критерия возможно провести следующую классификацию антикоррупционной экспертизы нормативных правовых актов и проектов правовых актов ФТС России:

- обязательная антикоррупционная экспертиза нормативных правовых актов и проектов правовых актов ФТС России, например, проводимая Правовым управлением ФТС России;

- инициативная антикоррупционная экспертиза нормативных правовых актов и проектов правовых актов ФТС России, проводимая общественными организациями и независимыми экспертами - физическими и юридическими лицами, аккредитованными Минюстом России на проведение антикоррупционной экспертизы нормативных правовых актов и их проектов.

О.Л. Зорин предлагает множество критериев, которые можно использовать при классификации антикоррупционной экспертизы нормативных правовых актов и их проектов, например:

1. По объекту осуществления - на предварительную и последующую;

2. По месту проведения экспертизы - внутреннюю и внешнюю;

3. По субъекту проведения - на государственную и независимую;

4. По способу проведения - на самостоятельную,

4 Кудашкин А.В. Антикоррупционная экспертиза: теория и практика. М.: НОРМА ИНФА-М, 2012. С. 48. 
а также проводимую в рамках осуществления правовой экспертизы;

5. По способу отбора документов на экспертизу: тотальную, выборочную, тематическую, контрольную, комплексную;

6. По результатам антикоррупционной экспертизы: обязательную и рекомендательную. ${ }^{5}$

Применительно к рассматриваемой нами классификации антикоррупционной экспертизы нормативных правовых актов и проектов правовых актов ФТС России, при использовании предложенных О.Л. Зориным критериев, полагаем возможным следующую классификацию:

По объекту осуществления:

- предварительная антикоррупционная экспертиза нормативных правовых актов и их проектов ФТС России, которая проводится ФТС России, независимыми экспертами, Минюстом России и пр. в отношении проектов нормативных правовых актов ФТС России на стадии подготовки проекта нормативного правового акта

- последующая антикоррупционная экспертиза нормативных правовых актов и их проектов ФТС России, которая осуществляется в процессе правового мониторинга.

2. В зависимости от места проведения экспертизы антикоррупционной экспертизы нормативных правовых актов и их проектов ФТС России:

- внутренняя антикоррупционная экспертиза нормативных правовых актов и их проектов ФТС России, проводимая Правовым управлением ФТС России;

- внешняя антикоррупционная экспертиза нормативных правовых актов и их проектов ФТС России, проводимая, осуществляемая независимыми экспертами, Минюстом России.

3. Исходя из субъекта проведения, О.Л. Зорин выделяет государственную и независимую антикоррупционную экспертизу нормативных правовых актов и их проектов.

Нам представляется возможным несколько уточнить указанный критерий классификации и предложить провести дифференциацию антикоррупционной экспертизы нормативных правовых актов и их проектов ФТС России в зависимости от статуса субъектов, проводящих антикоррупционную экспертизу

5 Зорин О.Л. Правовой механизм проведения антикоррупционной экспертизы нормативно-правовых актов в области обороны: теоретико-правовой аспект // Электронное научное издание Военное право. 2010. № 2-2010. С. 11-23. нормативных правовых актов и их проектов ФТС России на:

- официальную (государственную), проводимую ФТС России, Минюстом России, органами прокуратуры;

- независимую, проводимую общественными организациями и независимыми экспертами - физическими и юридическими лицами, аккредитованными Минюстом России на проведение антикоррупционной экспертизы нормативных правовых актов и их проектов.

4. Следующий критерий: по способу проведения. Исходя из него, возможна классификация антикоррупционной экспертизы нормативных правовых актов и их проектов ФТС России на:

- самостоятельная антикоррупционная экспертиза нормативных правовых актов и их проектов ФТС России, например, проводимая независимыми экспертами или органами прокуратуры в процессе анализа действующих нормативных правовых актов ФТС России;

- антикоррупционная экспертиза нормативных правовых актов и их проектов ФТС России, проводимая в рамках осуществления правовой экспертизы, в данном случае антикоррупционная экспертиза нормативных правовых актов и их проектов ФТС России является стадией правовой экспертизы.

5. По способу отбора документов антикоррупционную экспертизу нормативных правовых актов и их проектов ФТС России можно классифицировать на:

- тотальную антикоррупционную экспертизу нормативных правовых актов и их проектов ФТС России, проводимую в процессе правового мониторинга, например, антикоррупционная экспертиза всех нормативных правовых актов и их проектов ФТС России за определенный период времени (год, квартал, месяц);

- выборочную антикоррупционную экспертизу нормативных правовых актов и их проектов ФТС России, например, антикоррупционная экспертиза, проводимая независимыми экспертами;

- тематическую антикоррупционную экспертизу нормативных правовых актов и их проектов ФТС России, например, антикоррупционная экспертиза нормативных правовых актов и их проектов ФТС России в сфере таможенного оформления и таможенного контроля;

- контрольную антикоррупционную экспертизу нормативных правовых актов и их проектов ФТС России, проводимую органами прокурату- 
ры в отношении нормативных правовых актов ФТС России;

- комплексную антикоррупционную экспертизу нормативных правовых актов и их проектов ФТС России (проводится несколькими экспертами, обладающими специальными знаниями в одной области, либо экспертами в разных областях знаний), например, в процессе издания совместных нормативных правовых актов несколькими федеральными органами исполнительной власти с участием ФТС России

6. Следующий критерий, предложенный О.Л. Зориным: по результатам антикоррупционной экспертизы. Нам представляется необходимым несколько уточнить заявленный критерий: в зависимости от обязательного характера заключения антикоррупционную экспертизу проектов нормативных правовых актов ФТС России можно дифференцировать на:

- заключение носит рекомендательный характер (независимая антикоррупционная экспертиза);

- заключение носит обязательный характер (проведенная Минюстом России антикоррупционная экспертиза нормативных правовых актов, затрагивающих права, свободы и обязанности человека и гражданина, устанавливающих правовой статус организаций или имеющих межведомственных характер, при их государственной регистрации) ${ }^{6}$.

Заслуживает внимания, основания для классификации антикоррупционной экспертизы, предложенные Е.В. Каменской и А.А. Рождествиной. ${ }^{7}$ Применительно к антикоррупционной экспертизе нормативных правовых актов и их проектов ФТС России, представляется возможным использование следующих критериев, разработанных Е.В. Каменской и А.А. Рождествиной:

1. В зависимости от количества субъектов (экспертов), участвующих в ее производстве:

- единоличная антикоррупционная экспертиза нормативных правовых актов и их проектов ФТС России, например, проводится долж-

6 Куракин А.В. Административно-правовые средства предупреждения и пресечения коррупции в системе государственной службы зарубежных государств. - Домодедово, 2007.

7 Каменская Е.В., Рождествина А.А. Независимая антикоррупционная экспертиза: научно-практическое пособие // Справочно-правовая система КонсультантПлюс. ностным лицом Правового управления ФТС России;

- комиссионная или комплексная антикоррупционная экспертиза нормативных правовых актов и их проектов ФТС России (данный вид был рассмотрен нами выше).

2. Исходя из регулярности проведения:

- временная антикоррупционная экспертиза нормативных правовых актов и их проектов ФТС России, например, оценка проекта нормативного правового акта ФТС России независимым экспертом;

- систематическая антикоррупционная экспертиза нормативных правовых актов и их проектов ФТС России (проводится регулярно). Примером может послужить деятельность должностных лиц Правового управления ФТС России по проведению антикоррупционной экспертизы нормативных правовых актов и их проектов ФТС России.

3. В зависимости от количества выявленных коррупциогенных факторов:

- антикоррупционная экспертиза нормативных правовых актов и их проектов ФТС России, в ходе проведения которой выявлен один или несколько коррупциогенных факторов;

- антикоррупционная экспертиза нормативных правовых актов и их проектов ФТС России, в ходе проведения которой анализируется весь акт на коррупциогенность, выявляются все коррупциогенные факторы.

4. В зависимости от стадии разработки, принятия или действия нормативных правовых актов антикоррупционная экспертиза нормативных правовых актов и их проектов ФТС России подразделяется на:

- превентивная (на проекты нормативных правовых актов);

- текущая (на действующие нормативные правовые акты);

- последующая (при мониторинге применения данного акта).

Интерес представляет критерий, предложенный коллективом авторов под руководством Т.Я. Хабриевой. ${ }^{8}$ Ученые предлагают в качестве основания - по ситуациям, при которых проводится антикоррупционная экспертиза. Применительно к антикоррупционной экспертизы нормативных правовых актов

8 Коррупция: природа, проявления, противодействие. Монография/ под ред. Т.Я. Хабриевой. М.: ИД «Юриспруденция», 2012. С. 460. 
и проектов правовых актов ФТС России, возможна следующая классификация:

- $\quad$ антикоррупционная экспертиза нормативных правовых актов и проектов правовых актов ФТС России, проводимая в ходе правовой экспертизы должностными лицами Правового управления ФТС России;

- антикоррупционная экспертиза нормативных правовых актов и проектов правовых актов ФТС России, проводимая Минюстом России при государственной регистрации нормативных правовых актов ФТС России;

- антикоррупционная экспертиза нормативных правовых актов и проектов правовых актов ФТС России, проводимая при мониторинге правоприменения.

На наш взгляд, можно выделить следующие классификации видов антикоррупционной экспертизы нормативных правовых актов и проектов правовых актов ФТС России, которые будут полезны в практической деятельности:

1. Предлагаем провести классификацию, исходя из оснований, закрепленных Федеральным законом от 17.07.2009 № 172-Ф3 «Об антикоррупционной экспертизе нормативных правовых актов и проектов нормативных правовых актов». Данный закон определяет круг экспертов, которые могут проводить антикоррупционную экспертизу нормативных правовых актов и проектов правовых актов, исходя из этого, считаем целесообразным, выделить классификацию антикоррупционной экспертизы нормативных правовых актов и проектов правовых актов ФТС России по субъектному составу на проводимую:

- ФТС России;

- Минюстом России;

- независимыми экспертами;

- прокуратурой Российской Федерации.

2. Следующее основание для классификации: исходя из признаков антикоррупционной экспертизы. Так как Федеральным законом от 17.07.2009 № 172-Ф3 «Об антикоррупционной экспертизе нормативных правовых актов и проектов нормативных правовых актов» определены цели проведения антикоррупционной экспертизы нормативных правовых актов и проектов правовых актов, данный критерий может быть так же положен в основу классификации. В зависимости от цели антикоррупционную экспертизу нормативных правовых актов и проектов правовых актов ФТС России можно дифференцировать как:

- направленную на выявление норм, содержащих коррупциогенные факторы;
- $\quad$ направленную на устранение норм, содержащих коррупциогенные факторы.

3. Следующий критерий, который можно использовать при классификации антикоррупционной экспертизы нормативных правовых актов и проектов правовых актов ФТС России: в зависимости от стадии проведения:

- проводимую при подготовке проектов нормативных правовых актов ФТС России, например, анализ Минюстом России проектов нормативных правовых актов ФТС России;

- проводимую в процессе правового мониторинга нормативных правовых актов ФТС России.

4. Еще одно основание: в зависимости от содержания заключения, оформляемого после проведения антикоррупционной экспертизы проектов нормативных правовых актов ФТС России возможна следующая классификация:

- заключение содержит указание на выявленные коррупциогенные факторы;

- заключение содержит сведения, указывающие на отсутствие коррупциогенных факторов.

5. Следующее основание: в зависимости от объема антикоррупционной экспертизы нормативных правовых актов и проектов нормативных правовых актов ФТС России:

- единичная антикоррупционная экспертиза нормативных правовых актов и проектов нормативных правовых актов ФТС России. В данном случае проводится экспертиза лишь конкретных проектов нормативных правовых актов или нормативных правовых актов ФТС России;

- антикоррупционная экспертиза взаимосвязанных проектов нормативных правовых актов и (или) нормативных правовых актов ФТС России. Например, в процессе осуществления правовой экспертизы проекта нормативного правового акта будут выявлены нормативные правовые акты, связанные с рассматриваемым, в таком случае необходимо проведение антикоррупционной экспертизы всех связанных между собой нормативных правовых актов ФТС России.

Таким образом, необходимость классификации видов антикоррупционной экспертизы нормативных правовых актов и проектов нормативных правовых актов ФТС России обусловлена сложностью и многоаспектностью изучаемого нами института, а также для определения взаимосвязи входящих в него элементов. 


\section{Библиография}

1. Михалкин Н.В. Логика и аргументация в судебной практике. СПб., 2004. С. 41.

2. З Закиров И.А. Правовая экспертиза: дис. ... канд. юрид. наук. Н.Новгород, 2008. С. 10.

3. Кудашкин А.В. Антикоррупционная экспертиза: теория и практика. М.: НОРМА ИНФА-М, 2012. С. 48.

4. Зорин О.Л. Правовой механизм проведения антикоррупционной экспертизы нормативно-правовых актов в области обороны: теоретико-правовой аспект // Электронное научное издание Военное право. 2010. № 2-2010. С. 11-23.

5. Каменская Е.В., Рождествина А.А. Независимая антикоррупционная экспертиза: научно-практическое пособие // Справочно-правовая система КонсультантПлюс. 6. Куракин А. В. Реформирование государственной службы России должно иметь антикоррупционную направленность // Российская юстиция. - 2002. - № 7. 7. Куракин А.В. Административно-правовые средства борьбы с коррупцией в системе государственной службы // Журнал российского права. - 2003. - № 7. 8. Куракин А.В. Вопросы использования зарубежного опыта борьбы с коррупцией в правовом регулировании государственно-служебных отношений // Государство и право. - 2003. - № 8. 9. Куракин А.В. Правовые средства предупреждения и пресечения коррупции в системе государственной службы Российской Федерации (теоретико-административные аспекты). - М., 2004. 10. Куракин А.В., Савостин А.А. Процедуры, обусловленные прохождением государственной гражданской службы Российской Федерации // Право и политика. - 2004. - № 8. 11. Куракин А.В. Административно-правовые средства предупреждения и пресечения коррупции в системе государственной гражданской службы Российской Федерации. - М., 2005. 12. Куракин А.В. Административно-правовые средства предупреждения и пресечения коррупции в системе государственной службы зарубежных государств. - Домодедово, 2007. 13. Коррупция: природа, проявления, противодействие. Монография/ под ред. Т.Я. Хабриевой. М.: ИД «Юриспруденция», 2012.

6. Куракин А.В., Юлегина Е.И. Административные регламенты исполнения государственных функций и оказания государственных услуг в области осуществления антикоррупционной экспертизы нормативных правовых актов и их проектов // NB: Административное право и практика администрирования. - 2013. - 6. - С. 54 - 82. URL: http://www.e-notabene.ru/al/article_9040.html

\section{References}

1. Mikhalkin N.V. Logika i argumentatsiya v sudebnoi praktike. SPb., 2004. S. 41.

2. Zakirov I.A. Pravovaya ekspertiza: dis. ... kand. yurid. nauk. N.Novgorod, 2008. S. 10.

3. Kudashkin A.V. Antikorruptsionnaya ekspertiza: teoriya i praktika. M.: NORMA INFA-M, 2012. S. 48.

4. Zorin O.L. Pravovoi mekhanizm provedeniya antikorruptsionnoi ekspertizy normativno-pravovykh aktov v oblasti oborony: teoretiko-pravovoi aspekt // Elektronnoe nauchnoe izdanie Voennoe pravo. 2010. № 2-2010. S. 11-23.

5. Kamenskaya E.V., Rozhdestvina A.A. Nezavisimaya antikorruptsionnaya ekspertiza: nauchno-prakticheskoe posobie // Spravochno-pravovaya sistema Konsul'tantPlyus. 6. Kupakin A. V. Reformirovanie gosudarstvennoi sluzhby Rossii dolzhno imet' antikorruptsionnuyu nappavlennoct' // Rossiiskaya yuctitsiya. - 2002. - № 7. 7. Kupakin A.V. Adminictpativnopravovye sredstva bor’by s korruptsiei v sisteme gosudarstvennoi sluzhby // Zhupnal pocciickogo prava. - 2003. - № 7. 8. Kupakin A.V. Boppocy ispol'zovaniya zapubezhnogo opyta bor'by s korruptsiei v pravovom pegulipovanii gosudarstvennosluzhebnykh otnoshenii // Gocudapctvo i pravo. - 2003. - № 8. 9. Kupakin A.V. Ppavovye sredstva preduprezhdeniya i presecheniya korruptsii v sisteme gosudarstvennoi sluzhby Rossiiskoi Federatsii (teopetiko-administrativnye aspekty). - M., 2004. 10. Kupakin A.V., Cavoctin A.A. Protsedury, obuslovlennye prokhozhdeniem gosudarstvennoi grazhdanskoi sluzhby Rossiiskoi Federatsii // Pravo i politika. - 2004. - № 8. 11. Kupakin A.V. Adminictpativno-pravovye sredstva preduprezhdeniya i presecheniya korruptsii v sisteme gosudarstvennoi grazhdanskoi sluzhby Rossiiskoi Federatsii. M., 2005. 12. Kupakin A.V. Adminictpativno-pravovye sredstva preduprezhdeniya i presecheniya korruptsii v sisteme gosudarstvennoi sluzhby zarubezhnykh gosudarstv. - Domodedovo, 2007. 13. Korruptsiya: priroda, proyavleniya, protivodeistvie. Monografiya/ pod red. T.Ya. Khabrievoi. M.: ID «Yurisprudentsiya», 2012.

6. Kurakin A.V., Yulegina E.I. Administrativnye reglamenty ispolneniya gosudarstvennykh funktsii i okazaniya gosudarstvennykh uslug v oblasti osushchestvleniya antikorruptsionnoi ekspertizy normativnykh pravovykh aktov i ikh proektov // NB: Administrativnoe pravo i praktika administrirovaniya. - 2013. - 6. - C. 54 - 82. URL: http:// www.e-notabene.ru/al/article_9040.html 